\title{
Economic Freedom And Investment Efficiency In The MENA Region
}

\author{
Asma'a Al-Amarneh, Applied Science Private University, Jordan
}

\begin{abstract}
The purpose of this study is to investigate the effect of economic freedom level on investment efficiency; predicted by market return and volatility; using data covering the period from 1996 tell 2015 for the MENA region countries. Simple regression models and multivariate regression models were applied to test our hypothesis. The results show that the economic freedom level has a little impact on market return, and the capital market performance get better as the government regulations get highly efficient and the financial system is accessible and efficiently functioning. In the same time, the evidence points out that economic freedom decrease market returns' volatility (risk), indicating that; if government's regulation in banking and financial systems doesn't assure transparency and honesty, then financial markets efficiency will be hindered, the cost of financing will increase and the completion will be limited. Keeping in mind that the two fundamental aspects of investment are risk and return; it is obvious that economic freedom enhances the risk-return investment efficiency in the MENA region.
\end{abstract}

Keywords: Economic Freedom; Investment Efficiency; MENA Region

\section{INTRODUCTION}

apital, labor and technology have been used as determinants of growth in economy; and many researchers have assured that economic freedom is an important determinant of the nations' wealth, i.e. Bauer (1957,1978,1981,1984), Sen (1997/1999/2003), Friedman (1982), Friedman and Friedman (1980/1998), de Soto (2000), and Scully (1988, 2002).

The Economic freedom is an engine that drives the prosperity in the world and it is the difference between why some societies grow while the others do not. It is widely believed that; the level of economic freedom of any country is related to its equity market capitalization and returns. In $1997 \mathrm{La}$ Porta et al. reported that legal environment of the country is positively affecting the size and extent of its capital market. They argue that; countries with stronger legal protections for investors have larger and broader capital markets.

Levine and Zervos (1998) found that; after capital control liberalization the contribution of the equity market on the country's GDP increased and became more noticeable.

Henry (2000) concludes that as a result of opening stock market to foreign investments, the cost of capital in this market will decreased making investment in this country more profitable and attractive.

Li (2002) found that countries with higher economic freedom and stronger shareholder protection have a higher relative market capitalization as a percentage of GDP. While Ritter (2005) shows that economic growth negatively affecting equity returns over the period 1900-2002.

In his cross-country study during 1970-2002; Stocker (2005) founds that equity return is directly related to increase in economic freedom level depending on different proxies for economic freedom measures.

Lawson and Saurav (2008) examine the effect of economic freedom of North America (EFNA) index on stock market returns of firms located in several of the United States. They found that firms located in states with increasing economic freedom experience higher stock market returns. But they could not find evidence that this is useful as an investment strategy. 
Chen and Huang (2009) examine how equity performance and volatility affected by the government intervention. They found that economic freedom weakly affect capital market return, while stability increased by little government intervention.

Pelaez (2009) study the statistical significance of the difference between five groups of countries that differ in their economic freedom level, he found that the less and significant level of economic freedom was in the group of Islamic countries (including Jordan) and their economic freedom level was declining during the last 13 years.

Smimou and Karabegovic (2010) study the relationship between economic freedom level and stock return in Middle East and North Africa (MENA) equity markets from 2000 to 2007. The results show that the overall index of economic freedom positively affects the stock return; also all pillars of this index have a significant effect on equity return, too. The most significant elements were legal structure and property rights.

Rasiah, Ying and Solarin (2016) conducted study to investigate the relationship between each element of the economic freedom index and the stock returns in the Malaysian's stock exchange during the period 1995-2013. They used CAPM to calculate the stock return and apply the pooled OLS to test the study hypotheses. The results show that there is no significant long run relationship between each element of the index and the stock return, the same result founded when testing the overall effect of the index.

The economic freedom index prepared by the Heritage Foundation measures the economic performance of a certain country depending on comprehensive and broad areas, and composes of main four pillars: rule of low, limited government, regularity efficiency and open market.

Our study aims to analyze the economic freedom level in each country in MENA region and its effect on each national capital market (performance and volatility).First, by examining the effect of the index as a whole, then study the effect of each pillar separately.

The paper is organized as follows: section 2 outlines the research methodology; section 3 Defines variables; section 4 describes data and related statistics; section 5 reports our empirical findings; section 6 summarizes the results and conclusions.

\section{RESEARCH METHODOLOGY}

The government intervention in the capital market is reflected by the pricing of capital, so the performance of the capital market will be affected. Accordingly, the mean-variance investment efficiency will be affected, too. This paper aimed to investigate the effect of the degree of government intervention on capital market performance and test the following hypotheses:

Hypothesis 1: The lower the economic freedom level, the lower the market returns.

Hypothesis 2: The lower the economic freedom level, the higher the market volatility.

A simple regression model will be used to test the effect of each component of economic freedom index on market return and market volatility, and then a multiple regression will be used to test the effect of all components on market return and volatility.

\section{VARIABLES DEFINITION}

The study used two main sources of data; the economic freedom index prepared and published by the Heritage Foundation ${ }^{1}$ was used as proxy for government intervention level in selected while data related to market performance and volatility was extracted from publications of each MENA region country's stock exchange. According to availability of required data the following countries were selected: United Arab Emirates, Bahrain, Kuwait, Qatar,

${ }^{1}$ http://www.heritage.org/index/ 
Oman, Saudi Arabia, Egypt, Tunisia, Morocco, Lebanon and Jordan. Other region countries Yemen, Iraq, Algeria, Libya and Syria are excluded from the sample because required data concerning economic freedom index or market index are not available.

The data cover the period from 1996-2015, and 11 countries, with total sample size 231 country-year observations for each variable.

\section{Dependent Variables}

This paper aims to examine the effect of economic freedom on market return and volatility. Market return is measured by the percentage change in market index for each year, while market volatility measured by the standard deviation of the market return.

\section{Independent Variables}

Several indexes are available to indicate the economic freedom level of a country; such as International Country Risk (ICR) and the Economic Freedom Index (EFI) developed by the heritage Foundation which we use in our study as a proxy for degree of government interference in economic activity. The study includes the overall economic freedom index and the four pillars ${ }^{2}$ (rule of low, limited government, regularity efficiency and open market) of the index also sub elements related to each pillar as follows; Rule of law (property rights, freedom from corruption); Government size (fiscal freedom, government spending); Regulatory efficiency (business freedom, labor freedom, monetary freedom); and Market openness (trade freedom, investment freedom, financial freedom)

\section{DATA AND SUMMARY STATISTICS}

The comparison between the economic freedom index for the MENA Region, the World and Jordan during the period from 1995 -2016 show that average economic freedom index (a grading scale of 0-100) for the MENA region was near to those of the World (MENA region average $=58.55$, World average $=59.15$,) indicating that the whole world and the MENA region economy are mostly un-free on average, while Jordan index was (66.42) on average indicating a moderately free level compared to those of MENA region and the World.

Figure 1. Economic Freedom Index time line

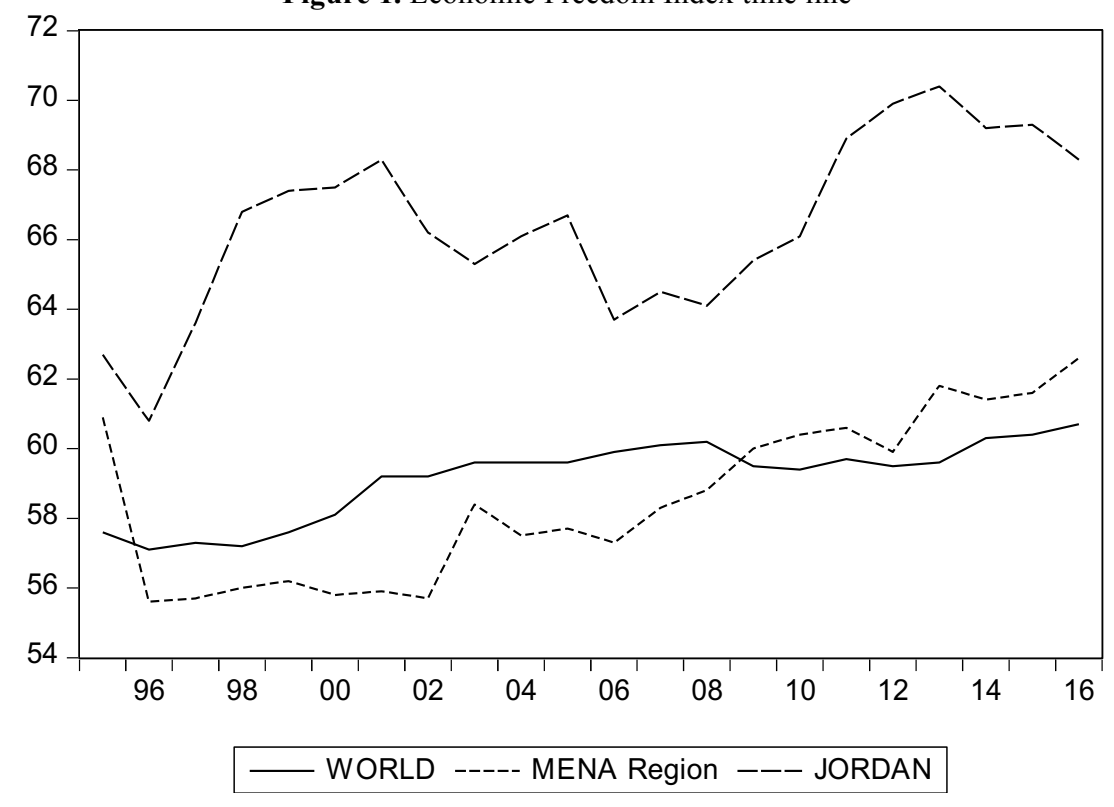

${ }^{2}$ (2015 Index of Economic Freedom Report, pp: 11-16) 
Table 1 presents the statistics for the dependent and independent variables. The figures show that the average economic freedom index for the MENA region (excluding Iraq, Syria, Yemen, Palestine, and Labia) was (63.74) out of (100) indicating that the MENA region economic is moderately free. Looking to the main four pillars of this index, the figures show that: concerning the rule of law the average index and the standard deviation values were $(51.54,15.23)$ indicating mostly un-free level of property rights and freedom from corruption with high variability between countries. The average index and standard deviation for property rights and freedom from corruption were $(52.64,15.25)$ and $(50.44,18.06)$, respectively, which means that the MENA region countries considered mostly un-free and the property rights are not protected effectively; furthermore a strong legal framework and systematic practices to curb corruption have yet to take shape in this region. The government sizes' pillar has an average of (76.98); it is the average for two main components (Fiscal freedom and government spending with average of 88.37 and 65.60 respectively). It is worth to know that; in the Index of Economic Freedom, the burden of all taxes is captured by measuring the overall tax burden from all forms of taxation as a percentage of total gross domestic products (GDP). The MENA region countries divided into two main groups according to this pillar; the first one is Saudi and Gulf Cooperation Council (GCC) countries, the second one is the group of Jordan, Lebanon and South Africa countries. The first group has the following figures: concerning taxation; no individual income tax, while corporate income tax can reach 45 percent, Saudi and GCC countries overall tax revenue range between less than 1 percent but not more than 8 percent of GDP, while the government expenditures range between 21 percent to 36 percent of domestic production. The public debt of Saudi and GCC ranges from 3 percent up to 44 percent of GDP. In the second group; individuals and corporations in Jordan, Lebanon and North Africa countries pay income tax ranged between 14 percent and 38 percent. These countries have an overall tax revenue ranges between 12 percent and 24 percent of GDP, while the public expenditure ranges between 21 percent and 36 percent of GDP. The public debt represents about 44 percent up to 139 percent of GDP.

It is clear that, Saudi and GCC governments depend on oil revenue to finance public expenditures, while other countries depend on tax revenues to finance the capital expenditure and public debt. All these in mind can explain the mostly free level of government size among the MENA region countries.

The regulatory efficiency index has an average value of (69.82) indicating un-free economies, this pillar consists of the following components with average value and standard deviation between brackets: business freedom (69.53, $10.71)$, labor freedom $(66.28,15.89)$ and the monetary freedom $(78.49,6.86)$. Burdensome and redundant regulations are the most common barriers to the free conduct of entrepreneurial activity and the procedures still time consuming. The overall labor regulations lake flexibility and labor market rigidity discourage dynamic job growth. We conclude that, the regulatory framework in the MENA region countries still lacks transparency and efficiency despite marginal improvements. The last pillar is the market openness measured by trade freedom, investment freedom, and financial freedom. The market openness index average and standard deviation were $(56.94,9.07)$ indicating mostly un-free level of economy's openness to the flow of goods and services from around the world and the citizen's ability to interact freely in the international marketplace. Mean values and standard deviations for the three components were as follow: the free trade component $(68.53,14.44)$ indicating a moderately free level of trade freedom, with average tariff rate between 3.9 to 8.1 percent with some restrictions on exports and imports. The investment freedom component $(49.56,14.18)$ the average value indicate that the foreign investment in MENA region countries is not free, also foreign investment is restricted in many sectors or capped at 49 percent. The MENA region countries have a mostly un-free financial freedom $(52.71,14.73)$. The competitive and modern financial sector provides a full range of services, although the state's presence remains considerable, in some countries the state dominates a significant portion of the banking sector. The capital market is not fully developed, but the stock exchange is open to foreign investors. 
Table 1. Descriptive statistics for all variables during 1996-2015.

\begin{tabular}{|c|c|c|c|c|c|}
\hline Variables & Mean & Median & Maximum & Minimum & Std. Dev. \\
\hline \multicolumn{6}{|l|}{ A. Dependent Variables } \\
\hline MARKET RETURN & -0000477 & -0.01615 & 0.527252 & -0.492800 & 0.187905 \\
\hline MARKET VOLATILITY & 24.20011 & 12 & 136.91 & 0.0638 & 29.38127 \\
\hline \multicolumn{6}{|l|}{ B. In-dependent Variable } \\
\hline OVERALLINDEX & 64.09 & 63.9 & 77.7 & 51.5 & 5.934928 \\
\hline \multicolumn{6}{|l|}{ Index four pillars } \\
\hline LAW & 51.54608 & 51 & 90 & 20 & 15.23329 \\
\hline government SIZE & 76.98687 & 77.45 & 93.1 & 49.7 & 8.612262 \\
\hline $\begin{array}{l}\text { REGULATORY } \\
\text { EFFICIENCY }\end{array}$ & 69.82342 & 71 & 82.8 & 55 & 6.350526 \\
\hline MARKET OPENNESS & 56.94025 & 57.26667 & 79.26667 & 30.06667 & 9.078992 \\
\hline \multicolumn{6}{|l|}{ Index components } \\
\hline PROPERTY FREE & 52.64977 & 50 & 90 & 20 & 15.25271 \\
\hline CORRUPTION FREE & 50.4424 & 50 & 90 & 10 & 18.06897 \\
\hline FISCAL FREE & 88.37005 & 97.7 & 99.9 & 36.6 & 14.07678 \\
\hline GOV.SPENDING & 65.60369 & 68.1 & 95.1 & 0.8 & 12.85683 \\
\hline BUSINESS FREE & 69.52765 & 70 & 100 & 39.8 & 10.71873 \\
\hline LABOR FREE & 66.28017 & 70 & 97 & 21.7 & 15.89861 \\
\hline MONETARY FREE & 78.49908 & 79.2 & 94 & 58.4 & 6.860798 \\
\hline TRADE FREE & 68.53963 & 75 & 83.8 & 25 & 14.44988 \\
\hline INVESTMENT FREE & 49.56221 & 50 & 75 & 30 & 14.18029 \\
\hline FINANCIAL FREE & 52.71889 & 50 & 90 & 30 & 14.73467 \\
\hline \multicolumn{6}{|l|}{ C. Control Variable } \\
\hline GDPGROWTH \% & 4.597024 & 4.2 & 19.6 & -7.1 & 3.718998 \\
\hline MARKETCAPGDP & 58.92393 & 51.25 & 299 & 0.57 & 43.79511 \\
\hline
\end{tabular}

Dependent variables in this study show high variability represented by the standard deviation value (see Table 1 Panel A) for each variable as a result of differences between financial market size and performance in each country and the percentage of GDP growth rate and the market capitalization as a percentage of GDP (Panel C).

\section{RESULTS AND DISCUSSION}

The effect of each component will be tested separately using simple regression models (M1 to M12) then a multivariate regression (M13) was used to test the research hypothesis, after correcting for multi-co-linearity and hetroskedasity. Table 2 represents the result for all regression models to test Hypothesis 1.

The results show that the overall economic freedom index was negatively affecting the market return but this result is insignificant. Unexpectedly, the GDP growth rate was negatively but insignificantly affecting equity market return as realized by Ritter (2005), he thought that; countries with high economic growth have higher price to earnings and price to dividend indicators in their equity markets, which means that more capital were committed by the investors to receive the same dividends. Also, Siegel (1998) clarify that the negative association between stock return and the growth in per capita GDP was impounded into prices at the start of the period.

In addition, the result of simple regression models related to each component of the economic freedom index was shown in Table 2 the results predict that, only the business freedom component has a positive and statistically significant effect (at $5 \%$ level) on market retune, indicating that the regulatory efficiency is the most effective pillar that affect financial market return. 
Table 2. Testing the effect of economic Freedom Index components on market Return

\begin{tabular}{|c|c|c|c|c|c|c|c|}
\hline & Intercept & $\begin{array}{l}\text { Overall } \\
\text { Index }\end{array}$ & GDP Growth & $\begin{array}{c}\text { Property } \\
\text { rights }\end{array}$ & $\begin{array}{l}\text { Corruption } \\
\text { freedom }\end{array}$ & $\begin{array}{c}\text { Fiscal } \\
\text { freedom }\end{array}$ & Gov. spend \\
\hline M1 & $\begin{array}{c}1.148648 \\
(1.394859)\end{array}$ & $\begin{array}{l}-0.005341 \\
(-0.76049)\end{array}$ & & & & & \\
\hline M2 & $\begin{array}{c}0.673835 \\
(2.365141)^{* *}\end{array}$ & & $\begin{array}{c}-0.006297 \\
(-0.537352)\end{array}$ & & & & \\
\hline M3 & $\begin{array}{c}0.740116 \\
(2.191211)^{* *}\end{array}$ & & & $\begin{array}{c}-0.000730 \\
(-0.394453)\end{array}$ & & & \\
\hline M4 & $\begin{array}{c}0.685576 \\
(2.190962)^{* *}\end{array}$ & & & & $\begin{array}{c}0.000150 \\
(0.074521)\end{array}$ & & \\
\hline M5 & $\begin{array}{c}0.753988 \\
(1.315766)\end{array}$ & & & & & $\begin{array}{c}-0.000681 \\
(-0.172813)\end{array}$ & \\
\hline M6 & $\begin{array}{c}0.605303 \\
(1.451727)\end{array}$ & & & & & & $\begin{array}{c}0.001070 \\
(0.407650)\end{array}$ \\
\hline M7 & $\begin{array}{c}0.985213 \\
(1.739319)^{* * *}\end{array}$ & & & & & & \\
\hline M8 & $\begin{array}{c}0.613757 \\
(0.814130)\end{array}$ & & & & & & \\
\hline M9 & $\begin{array}{c}0.417318 \\
(1.547529)\end{array}$ & & & & & & \\
\hline M10 & $\begin{array}{c}0.979844 \\
(1.930649)^{* *}\end{array}$ & & & & & & \\
\hline M11 & $\begin{array}{c}0.951900 \\
(2.525801)^{* *}\end{array}$ & & & & & & \\
\hline M12 & $\begin{array}{c}1.072272 \\
(1.719239)^{* * *}\end{array}$ & & & & & & \\
\hline M13 & $\begin{array}{c}11.02317 \\
(8.036056)^{*}\end{array}$ & & $\begin{array}{c}-0.023229 \\
(-2.335486)^{* *}\end{array}$ & $\begin{array}{c}-0.010894 \\
(-3.085683)^{*}\end{array}$ & $\begin{array}{c}-0.001295 \\
(-0.174377)\end{array}$ & $\begin{array}{c}-0.054403 \\
(-4.459877)^{*}\end{array}$ & $\begin{array}{c}0.005782 \\
(2.734767)^{*}\end{array}$ \\
\hline M13 & $\begin{array}{c}10.62368 \\
(8.899903)^{*}\end{array}$ & & $\begin{array}{c}-0.02562 \\
(-2.64881)^{* *}\end{array}$ & $\begin{array}{c}-0.01209 \\
(-3.09009)^{*}\end{array}$ & $\begin{array}{c}-0.00064 \\
(-0.07932)\end{array}$ & $\begin{array}{c}-0.0446 \\
(-3.97173)^{*}\end{array}$ & $\begin{array}{c}0.006219 \\
(2.675083)^{*}\end{array}$ \\
\hline \multicolumn{8}{|c|}{ (Table 2 continued) } \\
\hline & $\begin{array}{c}\text { Labor } \\
\text { freedom }\end{array}$ & $\begin{array}{l}\text { Monetary } \\
\text { freedom }\end{array}$ & $\begin{array}{l}\text { Business } \\
\text { freedom }\end{array}$ & $\begin{array}{c}\text { Trade } \\
\text { freedom }\end{array}$ & $\begin{array}{c}\text { Investment } \\
\text { freedom }\end{array}$ & $\begin{array}{c}\text { Financial } \\
\text { freedom }\end{array}$ & Adjusted $R^{2}$ \\
\hline M1 & & & & & & & 0.832629 \\
\hline M2 & & & & & & & 0.832143 \\
\hline M3 & & & & & & & 0.831294 \\
\hline M4 & & & & & & & 0.831151 \\
\hline M5 & & & & & & & 0.831259 \\
\hline M6 & & & & & & & 0.831328 \\
\hline M7 & $\begin{array}{c}-0.002520 \\
(-1.006227)\end{array}$ & & & & & & 0.820605 \\
\hline M8 & & $\begin{array}{c}0.000789 \\
(0.092629)\end{array}$ & & & & & 0.831191 \\
\hline M9 & & & $\begin{array}{c}0.004857 \\
(2.067348)^{* *}\end{array}$ & & & & 0.834258 \\
\hline M10 & & & & $\begin{array}{c}-0.004566 \\
(-0.948285)\end{array}$ & & & 0.834588 \\
\hline M11 & & & & & $\begin{array}{c}-0.002414 \\
(-0.962278)\end{array}$ & & 0.832943 \\
\hline M12 & & & & & & $\begin{array}{c}-0.002988 \\
(-0.820700)\end{array}$ & 0.833380 \\
\hline M13 & $\begin{array}{c}0.002326 \\
(0.522275)\end{array}$ & $\begin{array}{c}0.014414 \\
(2.829322)^{*}\end{array}$ & $\begin{array}{c}0.010637 \\
(5.346101)^{*}\end{array}$ & $\begin{array}{c}-0.007634 \\
(-1.707785)^{* * *}\end{array}$ & $\begin{array}{c}0.000481 \\
(0.067642)\end{array}$ & $\begin{array}{c}0.021926 \\
(3.219247)^{*}\end{array}$ & $\begin{array}{c}0.974338 \\
(\text { F-stat }=151.1481)^{*}\end{array}$ \\
\hline M13 & $\begin{array}{c}0.001941 \\
(0.476955)\end{array}$ & $\begin{array}{c}0.01244 \\
(1.743257)^{* * *}\end{array}$ & $\begin{array}{c}0.013825 \\
(6.051363)^{*}\end{array}$ & $\begin{array}{c}-0.01164 \\
(-2.18427)^{* *}\end{array}$ & $\begin{array}{c}-0.00525 \\
(-0.70247)\end{array}$ & $\begin{array}{c}0.026574 \\
(3.08909)^{*}\end{array}$ & $\begin{array}{c}0.917032 \\
\text { F-stat }(44.70892)^{*}\end{array}$ \\
\hline
\end{tabular}


When multivariate regression was applied, the coefficient's sign for some variables were changed and became more significant. Property rights, fiscal freedom, government spending, monetary freedom, business freedom, trade freedom and financial freedom components became more significant compared with the simple regression results, while the sign for the following component changed from negative to positive: freedom from corruption, labor freedom, investment freedom and financial freedom. To summarize, the following components have a positive and significant effect on market return: government spending, monetary freedom, business freedom and financial freedom, suggesting that the performance of the stock market is getting better as government regulation is highly efficient and the financial system is accessible and efficiently functioning.

In the same manner we test hypothesis no (2) which predict the relationship between the level of economic freedom and market volatility. Table 3 presents that the overall economic freedom index has a negative significant effect in market volatility. These findings assure that; as government intervene less in the equity market that will be better for market stability and reduce the level of market volatility. As the value of adjusted R-square predicts; about 55 percent of capital market volatility in our sample can be explained by the overall economic freedom level. Again the GDP growth rate used as a control variable and models (M16-M25) report the result of testing simple regression models.

The results reveal that; only investment freedom and financial freedom have a negative significant effect on market volatility. Indicating that, equity market is less risk when the market is open and less restrictions on the movement of capital, both domestic and international. The multivariate regression (M26) shows that freedom from corruption has a positive effect on market volatility.

Table 3. Testing the effect of economic Freedom Index components on market volatility

\begin{tabular}{|c|c|c|c|c|c|c|c|}
\hline & Intercept & $\begin{array}{c}\text { Overall } \\
\text { Index }\end{array}$ & $\begin{array}{c}\text { GDP } \\
\text { Growth }\end{array}$ & $\begin{array}{l}\text { Property } \\
\text { rights }\end{array}$ & $\begin{array}{c}\text { Corruption } \\
\text { freedom }\end{array}$ & $\begin{array}{c}\text { Fiscal } \\
\text { freedom }\end{array}$ & Gov. spend \\
\hline M14 & $\begin{array}{c}53.67995 \\
(2.055899)^{* *}\end{array}$ & $\begin{array}{c}-0.705012 \\
(-1.725526)^{* * *}\end{array}$ & & & & & \\
\hline M15 & $\begin{array}{c}1.633672 \\
(0.398696)\end{array}$ & & $\begin{array}{c}0.964629 \\
(1.236895)\end{array}$ & & & & \\
\hline M16 & $\begin{array}{c}11.60545 \\
(2.166319)^{* *}\end{array}$ & & & $\begin{array}{c}-0.109212 \\
(-1.087049)\end{array}$ & & & \\
\hline M17 & $\begin{array}{c}6.399665 \\
(2.356103)^{* *}\end{array}$ & & & & $\begin{array}{c}-0.006175 \\
(-0.115302)\end{array}$ & & \\
\hline M18 & $\begin{array}{c}-2.453008 \\
(-0.355518)\end{array}$ & & & & & $\begin{array}{c}0.097909 \\
(1.218084)\end{array}$ & \\
\hline M19 & $\begin{array}{c}12.13455 \\
(0.935775)\end{array}$ & & & & & & $\begin{array}{c}0.087589 \\
(-0.464720)\end{array}$ \\
\hline M20 & $\begin{array}{c}0.945683 \\
(0.187309)\end{array}$ & & & & & & \\
\hline M21 & $\begin{array}{c}37.99097 \\
(1.687191)\end{array}$ & & & & & & \\
\hline M22 & $\begin{array}{c}10.03274 \\
(0.735014)\end{array}$ & & & & & & \\
\hline M23 & $\begin{array}{c}-1.597107 \\
(-0.382230)\end{array}$ & & & & & & \\
\hline M24 & $\begin{array}{c}14.28922 \\
(2.567928)^{* *}\end{array}$ & & & & & & \\
\hline M25 & $\begin{array}{c}10.64787 \\
(2.715013)^{*}\end{array}$ & & & & & & \\
\hline M26 & $\begin{array}{c}103.0595 \\
(34.05143)^{*}\end{array}$ & & $\begin{array}{c}0.261487 \\
(0.612544)\end{array}$ & $\begin{array}{c}-0.122700 \\
(-0.653033)\end{array}$ & $\begin{array}{c}0.366941 \\
(2.926577)^{*}\end{array}$ & $\begin{array}{c}-0.697502 \\
(-1.272364)\end{array}$ & $\begin{array}{c}-0.148789 \\
(-1.086604)\end{array}$ \\
\hline
\end{tabular}

(Table 3 continued on next page) 


\begin{tabular}{|c|c|c|c|c|c|c|c|}
\hline & $\begin{array}{c}\text { Labor } \\
\text { freedom }\end{array}$ & $\begin{array}{l}\text { Monetary } \\
\text { freedom }\end{array}$ & $\begin{array}{l}\text { Business } \\
\text { freedom }\end{array}$ & Trade freedom & $\begin{array}{c}\text { Investment } \\
\text { freedom }\end{array}$ & $\begin{array}{c}\text { Financial } \\
\text { freedom }\end{array}$ & Adjusted $\mathbf{R}^{2}$ \\
\hline M14 & & & & & & & 0.550130 \\
\hline M15 & & & & & & & 0.555955 \\
\hline M16 & & & & & & & 0.545821 \\
\hline M17 & & & & & & & 0.542827 \\
\hline M18 & & & & & & & 0.544725 \\
\hline M19 & & & & & & & 0.544169 \\
\hline M20 & $\begin{array}{c}0.108049 \\
(1.253031)\end{array}$ & & & & & & 0.534443 \\
\hline M21 & & $\begin{array}{c}-0.393455 \\
(-1.408161)\end{array}$ & & & & & 0.550726 \\
\hline M22 & & & $\begin{array}{c}0.055989 \\
(-0.301477)\end{array}$ & & & & 0.543227 \\
\hline M23 & & & & $\begin{array}{c}0.115026 \\
(1.853728)\end{array}$ & & & 0.546043 \\
\hline M24 & & & & & $\begin{array}{c}-0.155655 \\
(01.752794)^{* * *}\end{array}$ & & 0.548496 \\
\hline M25 & & & & & & $\begin{array}{c}-0.082283 \\
(-1.670648)^{* * *}\end{array}$ & 0.544803 \\
\hline M26 & $\begin{array}{c}0.012167 \\
(0.200914)\end{array}$ & $\begin{array}{c}0.353833 \\
(-1.553464) \\
\end{array}$ & $\begin{array}{c}-0.129192 \\
(-0.417566)\end{array}$ & $\begin{array}{c}-0.109658 \\
(-1.775418)^{* * *}\end{array}$ & $\begin{array}{c}-0.070927 \\
(-0.578731)\end{array}$ & $\begin{array}{c}0.424873 \\
(2.504346)^{* *}\end{array}$ & $\begin{array}{c}0.674642 \\
(\mathrm{~F}-\mathrm{stat}=11.83925)^{*}\end{array}$ \\
\hline
\end{tabular}

In particular, excessive and redundant government regulations provide opportunities for bribery and encourage illegitimate market interactions; as a result the volatility of the market will increase. The financial freedom was significant but with positive effect on market volatility which contradicts the result founded by the simple regression (M25). The overall components of economic freedom can explain about 73 percent of the variation in the cross-country equity market volatility.

\section{CONCLUSIONS}

This paper examines the effect of economic freedom level on investment efficiency; predicted by market return and volatility; using data covering the period from 1996 tell 2015 for the MENA region countries. Simple regression models and multivariate regression models were applied to test our hypothesis. The results show that the level of the economic freedom has a little effect on market return, and the capital market performance get better as the government regulations get highly efficient and the financial system is accessible and efficiently functioning. In the same time, the evidence points out that the level of economic freedom decrease the volatility in equity market returns, indicating that; if government's regulation in banking and financial systems doesn't assure transparency and honesty, then financial markets efficiency will be hindered, the cost of financing will increase and the completion will be limited. Keeping in mind that the two fundamental aspects of investment are risk and return; it is obvious that economic freedom enhances the risk-return investment efficiency in the MENA region. The study offers a practical insights on the pillars of economic freedom that policy makers must improve in order to mitigate or reduce equity volatility, therefore cost of equity financing.

\section{AUTHOR BIOGRAPHY}

Dr. Asma'a Al-Amarneh is currently an Associate Professor and head of Finance and Banking Sciences Department at Faculty of Business and Economics Sciences of Applied Science Private University. She holds BS.c. in Computer Science from The University of Jordan, also an MBA in Finance. She completed her Ph.D. degree in Finance at Amman Arab University for Higher Education.

Email: A_alamarneh@asu.edu.jo 


\section{REFERENCES}

Bauer, P.T. (1957). Economic Analysis and Policy in Underdeveloped Countries. Durham, N.C.: Duke University Press. (1978). Hostility to the Market in Less-Developed Countries. In K. Brunner (ed.). The First World and the Third World: Essays on the New International Economic Order, 169-89. Rochester, N.Y.: University of Rochester Policy Center Publications. (1981). Equality, the Third World, and Economic Delusion. Cambridge, Mass.: Harvard University Press. (1984). Reality and Rhetoric: Studies in the Economics of Development. Cambridge, Mass.: Harvard University Press.

Chen, R.C., Huang, Y.S. (2009). Economic freedom, equity performance and market volatility. International Journal of Accounting \& Information Management, 17(2), 189 - 197. DOI http://dx.doi.org/10.1108/18347640911001221

De Soto, H. (2000). The Mystery of Capital: Why Capitalism Triumphs in the West and Fails Everywhere Else. Basic Books. ISBN 0-465-01614-6

Friedman,Milton.(1982).Capitalism and Freedom. University of Chicago press, Chicago and London.20 ${ }^{\text {th }}$ Ed.

Friedman, M. \& Friedman, R.D. (1980). Free to choose: a personal statement. Harcourt Brace Jovanovich, New York (1998). Two lucky people: memoirs. Chicago University Press, Chicago.

Henry, P.B. (2000). Stock Market Liberalization, Economic Reform and Emerging Market Equity Prices. Journal of Finance. 55 , 529-64.

Lawson, R.A. \& Saurav, R. (2008). Economic Freedom and Equity prices among U.S States. Credit and Financial Management Review. 14(4), 25-35.

Levine, R. \& Zervos, S. (1998). Capital Control Liberalization and Stock Market Development. World Development, 26, 1169 83.

Li, K. (2002). What explains the growth of global equity markets? Canadian Investment Review. 15(3), 23-30

Pelaez, R.F. (2009). Economic freedom: A comparative study. Journal of Economics and Finance. 33(3), 246-58.

Rasiah, D., Ying, T.L., Solarin, S. (2016). Economic freedom index and stock returns in Malaysia. Theoretical and Applied Economics, XXIII(1), 213-236.

Ritter, J.R. (2005), Economic growth and equity returns. Pacific-Basin Finance Journal, 13(5), 489-503. DOI:10.1016/j.pacfin.2005.07.001

Scully, G.W. (1988). The institutional framework and economic development. Journal of Political Economy 96, 652-662

Scully, G.W. (2002). Economic Freedom. Government Policy and the Trade-Off Between Equity and Economic Growth, $113,77$. doi:10.1023/A:1020308831424

Sen, A. (1997). Resources, values and development. Harvard University Press, Cambridge, Mass. (1999). Development as freedom. Knoff, New York. (2003). Rationality and freedom. Belknap, New York.

Siegel, J.J. (1998). Stocks for the Long Run, Second edition. McGraw-Hill.

Smimou, K. \& Karabegovic, A. (2010). On the relationship between economic freedom and equity returns in the emerging markets: Evidence from the Middle East and North Africa (MENA) stock markets. Emerging Markets Review, 11(2), 119-151. https://doi.org/10.1016/j.ememar.2010.01.003

Stocker, M. (2005), Equity returns and economic freedom. Cato Journal. 25, 583-94. 


\section{NOTES}

